\title{
SiM
}

\section{Incorporating Ecosystem Services Into Economic Assessments of Restoration Projects}

\author{
By L. Allen Torell, Gregory L. Torell, and Rhonda K. Skaggs
}

\section{On the Ground}

- Rangeland restoration projects have defied quantitative economic assessment because of a lack of data and information that document benefits.

- From the literature, we assess the potential benefits of rangeland restoration efforts undertaken in New Mexico under the Restore New Mexico Project and conclude that the economic value of some of the goods and services generated are substantial, but little economic value exists for some of the ecosystem services used to justify the conservation effort.

- Given the complexity in measuring changes in ecosystem services following restoration efforts, we are pessimistic about the potential of placing a quantitative economic value on many rangeland ecosystem services. Identifying the expected direction of change and relative magnitude of change may be more useful and feasible.

Keywords: benefit-cost analysis, valuing rangeland ecosystem services, conservation and restoration practice benefits, range improvement economics, Restore New Mexico.

Rangelands 36(2):45-51

doi: 10.2111/RANGELANDS-D-13-00054.1

(C) 2014 The Society for Range Management

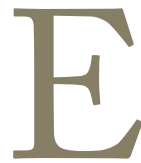

conomic evaluations of range improvements have traditionally valued the additional livestock capacity and beef production that can be obtained, but that production value usually justifies only $50 \%$ to $80 \%$ of the total range improvement cost on many western rangelands. ${ }^{1}$ Failure to include a measure of other environmental, ecological, and societal benefits of range improvements, beyond livestock production, implicitly assigns a value of zero to those outputs in the traditional economic assessment. This has led some to conclude that cost share programs for range improvements should be eliminated. ${ }^{2} \mathrm{~A}$ contrary view held by many rangeland managers is that it is morally, ethically, and professionally right to institute management practices that stop erosion, grow quality forage and vegetation, and improve rangeland conditions. Many rangeland managers holding these beliefs are of the opinion that conservation practices should not have to be economically justified. $^{3}$

The general inability to measure and quantify the environmental and ecological benefits of range improvements and restoration efforts has meant economics has a minimal role in range-improvement project-implementation decisions on public lands. ${ }^{4}$ As a current example, with restoration and rangeland health as justifications, the New Mexico Bureau of Land Management (BLM) and other collaborative cooperators take great pride in the restoration of more than 1.8 million acres of degraded rangeland to a healthy ecological state. ${ }^{5}$ About $\$ 41$ million dollars were spent on the New Mexico rangeland restoration effort since 2005 (D. Ellsworth, personal communication, May 2012). Other similar federally funded restoration efforts are in progress in other states. ${ }^{6,7}$ Economic evaluations are not included in project justifications, although there is an apparent increased awareness of the need to determine the value of ecosystem services economically in land management planning efforts. As noted in the 2011 Restore New Mexico newsletter, (Fig. 1) ${ }^{8}$ :

[BLM is] confident that Restore treatments are creating tremendous benefits for the land and wildlife habitat across the state. We've got countless before and after photos, testimony from our partners, and the impossible-to-deny reactions among the many visitors who have toured restored sites. Though we can see the success with our own eyes, this isn't enough. We want hard scientific data to support our efforts as well. (p. 1) 


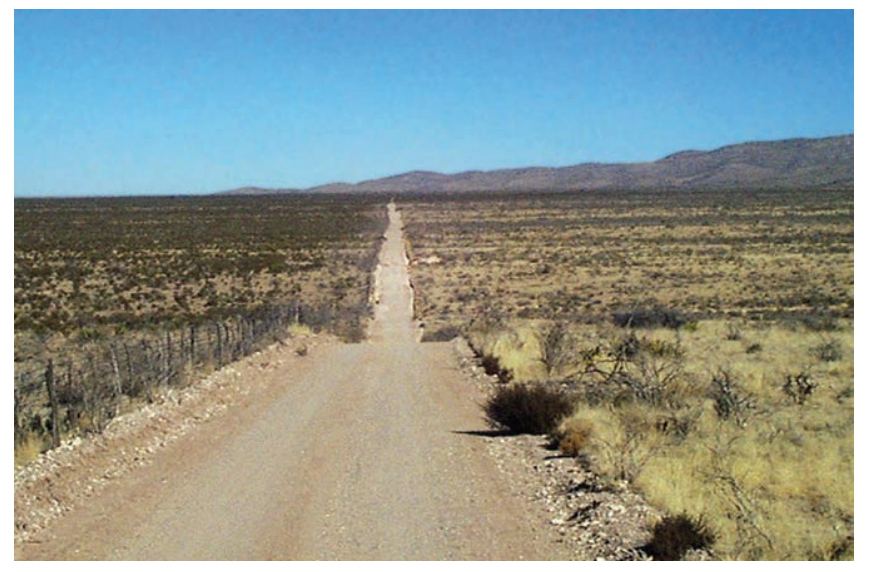

Figure 1. Successful creosote bush (Larrea tridentata) treatment (above the road) near Las Cruces, New Mexico, USA, costing about \$20/acre and treated in 1994. Photo by Kirk McDaniel, New Mexico State University.

With the need for scientific data as the motivation, rangeland monitoring at selected Restore New Mexico sites has been implemented. These efforts have documented positive ecosystem service responses, ${ }^{8}$ but a detailed quantification of changes in wildlife numbers, water yields, and other ecosystem service values and outputs has not been made. We believe that detailed quantification of economic benefits will not be forthcoming, either. Collaborating with economists, range and resource specialists can provide site-specific evaluations of selected rangeland ecosystem services, but there are major obstacles that will result in the questionable reliability of those estimates at various levels. In this article, we review those obstacles and reliability issues. We explore the economic potential for realizing positive economic benefits for the ecosystem goods and services identified for the Restore New Mexico brush control efforts and describe how an economic value might be placed on the various goods and services that are enhanced by the range improvement projects. We conclude that land managers should maintain a justified concern about site-specific, ecosystem service valuations because the linkages required to determine the value of rangeland ecosystem services are so poorly defined. Identifying an expected direction of change in goods and services provided may be the most realistic goal of restoration project assessments.

\section{Challenges in Determining the Value of Ecosystem Services}

In principle, an economic benefit-cost analysis compares the well-being of all affected parties both with and without project implementation. The most fundamental challenge for determining the value of ecosystem services is an adequate description and assessment of the linkages between the structure and functioning of natural systems and the goods and services derived under alternative actions. ${ }^{9}$ The first step in the valuation process is an assessment of expected change, what is being gained, and what is being given up by taking a particular action. Altered levels of some ecosystem services, like added forage for livestock, although highly variable across both space and time, can be measured and have traditionally been included in economic assessments of range improvements. ${ }^{1,10}$ The expected change for most other rangeland ecosystem services remains undocumented. An assessment of Natural Resource Conservation Service (NRCS) rangeland conservation efforts found that it was not possible to determine the magnitude or trend of conservation benefits originating from NRCS conservation investments because of the lack of information documenting the benefits. ${ }^{11, P 11}$

Some economists, rangeland scientists, and ecologist see promise in using the ecological site (ES) and State-andTransition Model (STM) framework to provide the necessary detail for measuring ecosystem provisioning under alternative management actions. ${ }^{12,13}$ Because the ecological model is soil- and vegetation-based, provisioning of different types of ecosystem goods and services can be predicted if there is a defined and predictable linkage to soil and vegetation characteristics. ${ }^{12}$ Provisioning of some rangeland outputs, however, are not related to soil and vegetation characteristics, and in most cases, key linkages are undefined and complex. Quantifying linkages and production relationships required for economic assessments is the major obstacle for valuing ecosystem goods and services.

Beyond measuring the change in resource provisioning, natural ecosystems present unique challenges for measuring economic value. Many of the goods and services derived from nature are not directly marketed. Stated preference methods and surveys (Box 1) are needed to elicit willingness to pay (WTP) values if the service is provided or willingness to accept payment if the service is not provided.

Alternative valuation approaches are appropriate in various situations, but values derived from different approaches can be very different. ${ }^{9}$ Numerous studies have found valuation responses in a survey setting to be larger than in some actual settings involving net economic commitments. ${ }^{14,15}$ Given consistent, observed disparities, National Oceanic and Atmospheric Administration guidelines suggest hypothetical bids should be deflated using a "divide by 2" rule unless calibrated with actual market data. ${ }^{14,15}$ Reliance on WTP studies

\section{Box 1. Stated Preference Methods}

Revealed preference models assume that the preferences of consumers and economic values can be revealed from observed purchases. When prices are not available, as is true for many environmental and natural resource amenities, stated-preference methods rely on answers to carefully worded survey questions about monetary amounts, choices, ratings, and preferences. Stated-preference models include contingent valuation, attribute-based methods, and paired comparisons. Nonmarket valuation procedures go well beyond what can be described here, and the interested reader is referred to resource and environmental economic text books and literature for additional detail about nonmarket valuation methods., ${ }^{9,16}$ 
to value ecosystem services should be of concern to land managers and decision makers given the hypothetical biases that have been shown to exist. Traditional benefit-cost studies of range improvement projects have sometimes underestimated the net economic benefit of improvement practices because the economic value of conservation benefits have been excluded; using nonmarket valuation studies with inflated values in the assessment has the potential to move the other way and overstate project benefits.

Extrapolating economic estimates of value (Benefit Transfer $)^{16}$ is another area of concern. In some cases, land agencies have used crude estimates of nonmarket benefits in planning documents with a single value for each output applied across broad areas and without consideration of local circumstances and conditions. ${ }^{4}$ Time constraints and regulations, however, mean it is not feasible to conduct original research for every resource valuation that arises. The biggest problem we see for benefit transfer application on rangelands is the few studies from which to extrapolate and project ecosystem service responses.

\section{Ecosystem Goods and Services Provided by the Restore New Mexico Project}

The Restore New Mexico Web site ${ }^{5}$ has numerous pictures and videos highlighting the perceived conservation benefits of the statewide rangeland restoration effort. The most obvious benefit noted is that many acres have been converted to what is considered a healthier ecological state (Fig. 1, for example). Other benefits mentioned include added forage; improved wildlife habitat and wildlife numbers; reduced fire danger; watershed benefits, including reduced soil erosion and offsite sediment deposits; and carbon sequestration. Next, we explore the potential magnitude of key ecosystem services identified and highlight how an economic value might be assigned to each.

\section{Rangeland Health}

Many perceive the major benefit of brush control efforts to be the improvement in rangeland health and condition. From that viewpoint, the "benefit" of the brush treatment shown in Figure 1 is the changed condition from the barren infested creosote bush (Larrea tridentata) area below the road, to the more diverse, grass-dominated area above the road.

Putting an economic value on the transition from a shrubdominated site to a grass-dominated site could use stated preference valuation procedures, which rely on answers to carefully worded survey questions about monetary amounts, choices, ratings, and preferences. ${ }^{9,16}$ As an example of the stated-preference approach, a contingent valuation study might ask respondents to state their valuation of altering the landscapes in Figure 1 or to indicate a range in which the value resides. With conjoint analysis, survey respondents could be given the alternatives of Figure 1 (and others) and asked to choose the preferred alternative or to rank the alternatives. It would be important that a representative sample of different types of land users be selected and that survey respondents clearly understand that it is the change in landscape attributes that is being valued.

An alternative, market-based valuation approach could rely on the real estate market to estimate landscape attribute values. Hedonic models are essentially a regression model used to explain differences in price. ${ }^{16}$ Those models have been widely used for real estate amenity valuation, including application to the ranch real estate market. ${ }^{17,18}$ Ranch saleappraisal data could be used, along with additional data defining the relative amounts of land included with the ranch sale in different ecological states and with different landscape attributes. Geographic information system overlays could be used to describe key amenity variables describing the landscape characteristics of the sale property. Variation in ranch sale price as landscape characteristics change would be measured by the regression results and the implied economic value of the landscape change could then be determined. Landscape attributes might be classified using the ecological site framework.

\section{Livestock Production}

Cooperative agreements for Restore New Mexico projects do not allow livestock operators to increase grazing capacity on BLM grazing allotments (L. Lister, personal communication, January 2011); yet, review of Figure 1 and Restore New Mexico projects clearly show that stocking rates are now more aligned with the actual carrying capacity of the land. Increased weaning weights and reproduction, along with increased grazing flexibility, are additional benefits described by cooperating livestock producers on recent tours of Restore New Mexico brush control sites.

Methods for assigning a grazing value are well documented and involve a before-treatment and after-treatment assessment of forage and livestock production rates. A finite treatment life is assumed, and future benefits are discounted to compute the net present value of the investment. ${ }^{10}$ Many times, the added grazing capacity is valued at the market lease rate for the forage, and conversions to actual production of livestock have also been used. ${ }^{19}$ Livestock production benefits generally justify about $50 \%$ to $80 \%$ of the total brush control treatment costs on a productive site, ${ }^{1}$ although that can vary greatly. Even without increases in the allowed stocking rate, livestock production advantages represent a major benefit of the Restore New Mexico brush control efforts. It is interesting to note, however, that the livestock benefit traditionally measured and included in range improvement assessments now has a minor role in the justification of current conservation efforts. We have moved from range improvements motivated by livestock production to a situation in which using more grass for cows as a justification for federally funded range improvement programs can potentially jeopardize funding and the support of the collaborative partners. Supervisory BLM personnel do not believe it would have been possible to get the project support needed to initiate the Re- 


\section{Box 2. Travel-Cost Method}

The travel-cost method assumes that the time and expenses that people incur to visit a recreational site represents the recreational participation price. Peoples' willingness to pay to visit a recreation site is estimated based on the number of trips they make at different distances and travel costs.

store New Mexico brush control effort if the project had been sold on the benefit of more grass for cows (L. Lister, personal communication, January 2011).

\section{Wildlife Benefits}

Restoring native vegetation and improving wildlife habit is a major focus of the Restore New Mexico program, and conversion to a grass-dominated savanna following brush control is expected to have significant benefits for many wildlife species, depending on habitat preferences. Bird species, including scaled quail (Callipepla squamata), Cassin's sparrows (Peucaea cassinii), and Eastern meadowlarks (Sturnella magna), populations have responded positively to the increased grass cover from the Restore treatments. ${ }^{20}$ Other game species, including quail, deer, elk, and antelope, are also expected to benefit from the Restore New Mexico treatments.

Key linkages for determining the value of the wildlife benefit of a brush control treatment require identifying altered habitat conditions with implications for altered wildlife numbers and the resulting changes in hunter activity. The travel-cost method (Box 2) has been widely used to estimate a willingness to pay for the recreational experience. ${ }^{16}$ For nongame species, an appropriate survey procedure could be used to elicit how public land users value the altered species diversity and richness. Similarly, others may value increased game species numbers and diversity without an interest in hunting.

Wildlife values for many different game and nongame species are available, based on numerous recreation studies, ${ }^{21}$ but measuring the benefits of habitat improvement goes beyond valuing the wildlife. Estimating how the wildlife population changes as habitats are altered is a major challenge.

\section{Watershed Benefits}

As noted by BLM Hydrologist, Michael McGee, "When we restore healthier native vegetation, soil erosion and runoff decrease, and overall, water conditions improve." He further notes that once target brush species are removed, more water is available for use by desirable grass, shrub, and tree species, allowing for the return of native vegetation. With more native plants, you get more water retention in the soil and less runoff and erosion. Published research shows this to be true. ${ }^{22-24}$ Others have gone further and perceived significant water-yield benefits, with stream and aquifer recharge, following brush eradication. The argument is that if evapotranspiration loss can be reduced by managing rangelands for a greater grass component and a lesser tree and shrub compo- nent, more water will be available for runoff and deep drainage. That argument has been shown to be true in a variety of humid, montane, and Mediterranean climates, where studies have tied increases in water yields to removal of trees and shrubs. ${ }^{25}$ On semiarid rangelands, however, water-yield benefits have not been demonstrated on scales that would greatly alter regional water supplies. Most upland range sites are too dry to realize increased water yields to streams and groundwater aquifers. ${ }^{24} \mathrm{~A}$ review of paired watershed studies concluded there was no increase in stream flow from tree and brush clearing at sites with less than $440 \mathrm{~mm}$ (17 inches) of mean annual precipitation. ${ }^{26}$ There appears to be little potential for increasing stream flows or groundwater recharge, in addition to forage and wildlife habitat benefit, unless annual precipitation exceeds about 450 to $500 \mathrm{~mm}$ (18 to 20 inches). ${ }^{24,27}$ Any claims that the Restore New Mexico brush control efforts on upland areas will increase water supplies are likely misguided, based on published watershed studies. ${ }^{i}$ Because the added water went to grow the added grass on the treated area, the added grazing capacity and wildlife habitat alteration capture the economic value of the increased water yield. On wet sites, where water yields are expected to increase, a market approach to determining economic value could be used. The added water yield could be valued in the market in which it could be sold.

Reduced erosion and improved water quality is another identified restoration benefit of Restore New Mexico brushcontrol efforts. As described by BLM rangeland specialist Ray Keller, ${ }^{5}$ on brush-infested areas with substantial bare ground, a rainfall event winds up as a "chocolate mess" down in the draw. The Restore New Mexico vegetation treatments potentially reduce polluted runoff and deposition of natural and human-made pollutants into lakes, rivers, wetlands, and ground waters. ${ }^{8}$ To value the services provided by a healthy watershed would require a determination of the expected, additional societal values because of the improved watershed. Water quality would be considered an input in various production processes. ${ }^{28}$

\section{Carbon Sequestration}

Implementing rangeland practices to enhance the sequestration of carbon has been proposed as a way to mitigate climate change. Other ecosystem benefits of added carbon sequestration include increased soil water-holding capacity, better soil structure, improved soil quality and nutrient cycling, and reduced soil erosion. ${ }^{29}$ Restoring degraded rangelands has been shown to change the amount of organic carbon stored in soil, ${ }^{29}$ although the net change remains uncertain, highly variable, and hard to predict. ${ }^{30}$ Carbon sequestration research on rangelands is a relatively new field, and scientists have

\footnotetext{
'This says nothing about salt cedar (Tamarix spp.) and riparian area restoration efforts, which are also included with the Restore New Mexico project. Salt cedar is often controlled with the objective of water conservation, and those riparian area treatments are not considered here.
} 
only begun to evaluate the carbon benefit of range management practices. Management practices that have been shown to improve the amount of carbon sequestered on rangelands include adjusting stocking rates, interseeding alfalfa, burning, fertilizing, and restoring degraded pastures. ${ }^{31}$

The processes governing carbon inputs and outputs on arid and semiarid rangelands are driven by the amount and timing of rainfall. ${ }^{32}$ Pools of organic carbon in soil are two to three times lower in semiarid than they are in mesic rangelands, ${ }^{33}$ and the desert rangelands of the southwest have relatively low potential for carbon sequestration. ${ }^{32}$ In addition, woody plants commonly contain more carbon in aboveground plant tissues than do nonwoody plants. A key question is whether the replacement of woody plants with grasses will lead to a net gain or net loss of carbon for the ecosystem as a whole. ${ }^{34}$

Economic evaluations of rangeland carbon sequestration have used a market-based approach, ${ }^{31,35}$ assuming carbon markets will return with cap-and-trade legislation. Relatively high carbon prices were needed to justify participation in the recent Rangeland Carbon Offset Program. ${ }^{31}$

\section{Reducing Fire Hazard}

A significant concern in recent years is increasingly large and severe wildfires occurring primarily because of changes in fuel loads, fuel composition, and fuel arrangement. Fuel management treatments have the ability to alter fires by changing the way they burn and behave, but it is a complex analysis. ${ }^{36,37}$ The benefit-cost assessment requires a definition of the relationships between the size and intensity of that wildfires as they relate to alternative fuel management treatments, climate variables, and site-specific characteristics. Potential benefits of fuel treatments will be site specific and must account for the cumulative cost of fuel treatments, the likelihood of wildfire events with and without treatment, the effects and costs of fire suppression and postfire restoration, and the effect of management actions and wildfires on resource conditions, structural damages, and saleable products, over time. ${ }^{37}$ Given the complexities, only a few studies have estimated net economic benefits of fuel treatments in forested areas, ${ }^{36,38}$ and only one recent study considered net economic benefits of fuel treatments on rangelands. ${ }^{39}$ Estimating the benefit of reduced fire hazard is hampered, particularly by undefined relationships and linkages.

\section{An Alternative Valuation Process}

The pessimistic view - that adequate definition of key linkages about the structure and function of rangeland systems limits our ability to provide reliable estimates of the economic value for many rangeland ecosystem goods and services-is disheartening and a continuing dilemma. Obviously, expanded benefit-cost assessments should be undertaken when sound data are available. With our current knowledge, however, identifying the expected direction of change and the relative magnitude of change may be more useful and feasible. This is the type of assessment proposed by the Sustainable Range- land Roundtable (SRR).ii The SRR framework compares the expected progression of social, economic, and resource conditions, when alternative management actions are followed. ${ }^{40,41}$ Assessment is more along the lines of the direction of change, the trade offs, and the expected strength of the change, rather than by applying values and conducting typical benefit-cost assessments. Expected biophysical and social-economic impacts are summarized as a relative ranking, not as a quantitative number like a benefits-costs ratio or a net present value calculation. Indicators of social, economic, and ecological sustainability are monitored over time, and impacts are assessed by decision- and policy-makers. Ideally, the indicators would help identify which data are important to collect so that more quantitative relationships can be defined in the future. It is left to decision- or policy-makers to determine whether the direction of change is "good" or "bad." We argue that, in most cases, this is the best that can reliably be done, given the current state of knowledge about the critical linkages required for rangeland ecosystem valuation. We are far from being able to reliably estimate the levels of goods and services provided under alternative management actions, to extrapolate those value estimates across the western rangelands, or to use those values to evaluate the trade offs in many management and policy decisions. It will require cross-discipline cooperation and research and monitoring efforts to describe and quantify the levels of key ecosystem goods and services realized under alternative management actions measured across broad landscapes. The value of the assessment exercise would be a more systematic consideration of the effects and trade offs of alternative management actions. Such an exercise would be better than a full-blown economic assessment based on best guesses and inappropriately extrapolated values.

\section{References}

1. Tanaka, J. A., M. Brunson, And L. A. Torell. 2011. A social and economic assessment of rangeland conservation practices. In: David D. Briske [ed.]. Conservation benefits of rangeland practices: assessment, recommendations, and knowledge gaps. Washington, DC, USA: USDA-Natural Resource Conservation Service. p. 371-422.

2. Holechek, J. L., And K. Hess, Jr. 1994. Brush control considerations: a financial perspective. Rangelands 16(5):193-196.

3. Nelson, R. H. 1995. Public lands and private rights: the failure of scientific management. Lanham, MD, USA: Rowman \& Littlefield. 373 p.

4. Nelson, R. H. 2006. Valuing nature: economic analysis and public land management, 1975-2000. American Journal of Economics and Sociology 65:525-557.

5. [BLM] Bureau of Land Management. 2013. Restore New Mexico Web site. Available at: http://www.blm.gov/nm/st/en/ prog/restore_new_mexico.html. Accessed 11 July 2013.

\footnotetext{
i"The ranking of alternatives is what we find appealing about the SRR framework, but alternative ranking models and processes could work equally well.
} 
6. [BLM] Bureau of Land Management. 2011. Healthy lands initiative. Available at: http://www.blm.gov/wo/st/en/info/ newsroom/2008/April/HLI_09_Fact_Sheets.html. Accessed 12 August 2013.

7. [USFS] U.S. Forest Service. 2013. Collaborative forest landscape restoration program. Available at: http://www.fs.fed.us/ restoration/CFLRP/. Accessed 1 August 2013.

8. [BLM] Bureau of Land Management. 2011. Restore New Mexico newsletter. Albuquerque, NM, USA: BLM. 19 p.

9. [NRC] National Research Council. 2005. Valuing ecosystem services: toward better environmental decision-making/ Committee on Assessing and Valuing the Services of Aquatic and Related Terrestrial Ecosystems, Water Science and Technology Board, Division on Earth and Life Studies. Washington, DC, USA: National Academies Press. 277 p.

10. Workman, J. P. 1986. Range economics. New York, NY: McMillan Publishing Co. 217 p.

11. Briske, D. D. [ED.] 2011. Conservation benefits of rangeland practices: assessment, recommendations, and knowledge gaps. [ed.] Washington, DC, USA: USDA-Natural Resource Conservation Service. 429 p.

12. Brown, J., And N. MacLeod. 2011. A site-based approach to delivering rangeland ecosystem services. Rangeland Journal 33:99-108.

13. TAYlor, M. H., And K. Rollins. 2012. Using ecological models to coordinate valuation of ecological change on western rangelands for ex post application to policy analysis. Western Economics Forum 11:13-21.

14. List, J. A., And J. F. Shogren. 1998. Calibration of the difference between actual and hypothetical valuations in a field experiment. Journal of Economic Behavior and Organization 37:193-205.

15. Loomis, J. 2011. What's to know about hypothetical bias in stated preference valuation studies? Journal of Economic Surveys 25:363-370.

16. Champ, P. A., K. J. Boyle, and T. C. Brown. 2003. A primer on nonmarket valuation. Dordrecht, The Netherlands: Kluwer Academic Publishers. 588 p.

17. Bastian, C. T., D. M. McLeod, M. J. Germino, W. A. ReinERs, AND B. J. Blas Ko. 2002. Environmental amenities and agricultural land values: a hedonic model using geographic information systems data. Ecological Economics 40:337-349.

18. Torell, L. A., B. Dixon, and D. McCollum. 2012. The market value of ranches and grazing permits in New Mexico 1996-2010. Las Cruces, NM, USA: New Mexico State University, Agricultural Experiment Station Report. 31 p.

19. Bartlett, E. T., L. A. Torell, N. R. Rimbey, L. W. Van TasSEll, AND D. W. McCollum. 2002. Valuing grazing use on public land. Journal of Range Management 55:426-438.

20. Coffman, J. M. 2011. Breeding bird responses to 30 years of grassland restoration on southern New Mexico public lands [master's thesis]. Las Cruces, NM, USA: New Mexico State University. $74 \mathrm{p}$.

21. Loomis, J., T. Kroeger, L. Richardson, and F. Casey. 2012. The benefit transfer and use estimating model toolkit. Avail- able at: http://dare.colostate.edu/tools/benefittransfer.aspx. Accessed 6 September 2012.

22. Sturges, D. L. 1983. Long-term effects of big sagebrush control on vegetation and soil water. Journal of Range Management 36:760-765.

23. Kuhn, T. J., M. R. George, D. Cao, and K. W. Tate. 2007. Juniper removal may not increase overall Klamath River Basin water yields. California Agriculture 61:166-171.

24. Нibbert, A. R. 1983. Water yield improvement potential by vegetation management on western rangelands. Water Resources Bulletin 19:375-381.

25. Wilcox, B. P., And T. L. Thurow. 2006. Emerging issues in rangeland ecohydrology: vegetation change and the water cycle. Rangeland Ecology E Management 59:220-224.

26. Bosch, J. M., and J. D. Hewlett. 1982. A review of catchment experiments to determine the effect of vegetation changes on water yield and evapotranspiration. Journal of Hydrology 55:323.

27. Wilcox, B. P. 2002. Shrub control and streamflow on rangelands: a process based viewpoint. Journal of Range Management 55:318-326.

28. Freeman, A. M. 2003. The measurement of environmental and resource values: theory and methods. 2nd ed. Washington, DC, USA: Resources for the Future. 516 p.

29. Derner, J. D., And G. E. Schuman. 2007. Carbon sequestration and rangelands: a synthesis of land management and precipitation effects. Journal of Soil \& Water Conservation 62:77-85.

30. Brown, J., J. Angerer, S. W. Salley, R. Blaisdell, and J. W. STUTH. 2010. Improving estimates of rangeland carbon sequestration potential in the US Southwest. Rangeland Ecology E Management 63:147-154.

31. Ritten, J. P., C. T. Bastian, and B. S. Rashford. 2012. Profitability of carbon sequestration in western rangelands of the United States. Rangeland Ecology \& Management 65:340-350.

32. Svejcar, T., R. Angell, J. A. Bradford, W. Dugas, W. Emmerich, A. B. Frank, T. Gilmanov, M. Haferkamp, D. A. Johnson, H. Mayeux, P. Mielnick, J. Morgan, N. Z. Saliendra, G. E. Schuman, P. L. Sims, and K. Snyder. 2008. Carbon fluxes on North American rangelands. Rangeland Ecology \& Management 61:465-474.

33. Derner, J. D., D. D. Briske, and T. W. Boutton. 2006. Grazing and ecosystem carbon storage in the North American Great Plains. Plant and Soil 280:77-90.

34. Diaz, D. D., H. Gosnell, and S. Charnley. 2009. Engaging western landowners in climate change mitigation: a guide to carbon-oriented forest and range management and carbon market opportunities. Portland, OR, USA: USDA-Forest Service, Pacific Northwest Research Station. General technical PNW report GTR. 801 p.

35. Ritten, J. P., C. T. Bastian, B. S. Rashford, J. Norton, U. Norton, S. I. Paisley, and P. Burgener. 2009. Can carbon find a home on the range? [poster] 2010 The Seventh AAEA, CAES, \& WAEA Joint Annual Meeting; 25-27 July 2010; Denver, Colorado, USA. Milwaukee, WI, USA: Agricultural and Applied Economics Association. p. 14-21. 
36. Mercer, D. E., J. P. Prestemon, D. T. Butry, and J. M. Pye. 2007. Evaluating alternative prescribed burning policies to reduce net economic damages from wildfire. American Journal of Agricultural Economics 89:63-77.

37. Kline, J. D. 2004. Issues in evaluating the costs and benefits of fuel treatments to reduce wildfire in the Nation's forests. Portland, OR, USA: USDA-Forest Service. 47 p.

38. Prestemon, J. P., K. L. Аbt, and R. J. Barbour. 2012. Quantifying the net economic benefits of mechanical wildfire hazard treatments on timberlands of the western United States. Forest Policy E Economics 21:44-53.

39. Taylor, M. H., K. Rollins, M. Kobayashi, and R. J. Tausch. 2013. The economics of fuel management: wildfire, invasive plants, and the dynamics of sagebrush rangelands in the western United States. Journal of Environmental Management 126:157173.

40. Fox, W. E., D. W. McCollum, J. E. Mitchell, L. E. Swanson, U. P. Kreuter, J. A. Tanaka, G. R. Evans, H. T. Heintz, R. P. Breckenridge, and P. H. Geissler. 2009. An integrated social, economic, and ecologic conceptual (ISEEC) framework for considering rangeland sustainability. Society and Natural Resources 22:593-606.

41. Kreuter, U. P., W. E. Fox, J. A. Tanaka, K. A. Maczko, D. W. McCollum, M. E. John, C. S. Duke, and L. Hidinger. 2012. Framework for comparing ecosystem impacts of developing unconventional energy resources on western US rangelands. Rangeland Ecology E Management 65:433-443.

Authors are Professor, Dept of Agricultural Economics and Agricultural Business, New Mexico State University, Las Cruces, NM 88003-8003, USA, atorell@nmsu.edu (L. A. Torell); PhD Candidate, Dept of Economics and Finance, University of Wyoming, Laramie, WY 82071, USA (G. L. Torell); and Professor, Dept of Agricultural Economics and Agricultural Business, New Mexico State University, Las Cruces, NM 88003-8003, USA (Skaggs). This research was supported by the New Mexico State University Agricultural Experiment Station and USDA-NIFA. 